\title{
Determinants of Firm's Financial Performance: An Empirical Study on Textile Sector of Pakistan
}

\author{
Ali Abbas (Corresponding Author) \\ Hailey College of Commerce, University of the Punjab Lahore, Pakistan \\ Tel: 92-333-897-4480 E-mail: mianali348@hotmail.com
}

\begin{abstract}
Zahid Bashir
Faculty of Finance at School of Business, Economics \& Management Sciences

Imperial College of Business Studies Lahore, Pakistan

Tel: 92-323-849-8515 E-mail: zahid.bashir.332@gmail.com
\end{abstract}

\begin{abstract}
Shahid Manzoor
Hailey College of Commerce, University of the Punjab Lahore, Pakistan
\end{abstract}

Tel: 92-313-413-1676 E-mail: shahidmanzoor09@yahoo.com

Muhammad Nadeem Akram

Mezan Bank, Quaid-e-Azam Industrial Estate Branch Lahore, Pakistan

Tel: 92-331-402-2421 E-mail: nadeemakram@live.com

Received: July 5, 2013 Accepted: July 18, 2013

doi:10.5296/ber.v3i2.3958 URL: http://dx.doi.org/10.5296/ber.v3i2.3958

\begin{abstract}
The current study aims to find out the determinants significantly affecting the firm's financial performance in textile sector of Pakistan for the period 2005-2010. The researcher used panel/longitudinal data set which are created with the help of State Bank of Pakistan's annual publication named as "Financial statement analysis of companies (non-financial) listed in KSE for the period 2005 to 2010 which is available at www.sbp.org.pk online. The researcher used one-way fixed effect model due the presence of cross-sectional fixed effect in the regression
\end{abstract}


results. The dependent variable was profitability as a measure of firm's financial performance while the independent variables were leverage, growth, firm's size, risk, tax, tangibility, liquidity and non-debt tax shield. The firm's performance in textile sector is significantly affected by Short term leverage, Size, risk, tax and non-debt tax shield while taking long term leverage as first independent variable, the leverage becomes insignificant along with tax factor. The textile sector should consider the above said factors because these factors significantly increasing or decreasing firm's financial performance. The findings of the current research are limited and applicable to non-financial sector of Pakistan only. It is not applicable to financial sector due to their difference of capital structure. In addition, the researcher used ROI as measure of firm's financial performance while the future research can have ROA, ROE, EPS etc as firm's financial performance.

Keywords: Firm's performance, Textile sector, Return on Investment

\section{Introduction}

There are a total number of 411 firms in non-financial sector of Pakistan which is subdivided into 12 sectors while Textile sector is the largest and the first sector which comprise of a total number of 164 firms which covers $40 \%$ of the overall non-financial sector of Pakistan. The researcher used the financial data of 139 firms of textile sector because the remaining firms missed some of the financial records required for analysis. The textile sector represent a large part of the non-financial sector of Pakistan, the financial performance of this sector may influence the performance of the other sectors. The basic and fundamental duty of every financial manager is to maximize the shareholder's wealth and to increase firm's value which is possible when the firm's financial performance can be increased. The researcher's aim during this research is to identify the number of factor that determines the firm's financial performance. The previous studies conducted on firm's performance indicates that a large number of factors affect significantly the firm's performance. David Durand (1952) presented different theories for starting the argument on firm's value. David Durand (1952) presented first theory with the name of Net Income (NI) approach, then after wards he presented Net Operating income approach and finally traditional approach to justify his opinion. He was of the view that increasing leverage can increase firm's performance but he could not provide the operational justification to validate his point of view. Modigliani and Miller (1958) in their theses revealed it is not mandatory that a firm using leverage or not can have difference in their value. For the validity of their research they presented an operational justification with the name of arbitrage process. The arbitrage process states that investor purchases shares or make investment at low prices and sales their investment or shares at high prices simultaneously in different markets. Modigliani and Miller (1963) also found that debt provide the tax shield advantage in the form of interest. A lot of studies afterwards reveal that corporate financial performance or firm's performance influenced by a number of factors that should keep in mind while making financial decision to increase a firm's performance. The researcher used the framework of Zeitun and Tian (1997). They used leverage, growth, size, tax, risk and tangibility to see their effect on corporate performance of Jordan non-financial sector. The researcher extended the regression model by including liquidity and non-debt tax shield (depreciation) to make this study more comprehensive. 


\subsection{Significance of the Study}

Textile sector is the largest industry in Pakistan. It consist of 164 firms which includes 145 firms related to spinning, weaving and finishing while 6 firms consist of made up textiles articles and the remaining 13 firms are related to other textiles items. From the last many years, Pakistani textile industry is facing a large number of crises due to continuous load-shedding from the last many years. A large number of firms in this sector have closed their operations because without electricity it is not possible to produce any product in textile sector. The remaining firms are forced to take loan for their survival in order to use generator or private electricity resources which are much costly. It has increased debt financing trend in this sector and the firm's performance is affected largely by this trend. APTMA has requested to Government of Pakistan to take some serious steps in order to rescue the textile industry for possible survival by controlling the problem of electricity and restructuring the outstanding loans. In this way PICIC commercial bank was previously establish to provide loan both short term and long term according to this sector need and recently NIB bank has been established for this purpose.

\subsection{Objective of the Study}

The Textile Sector covers $40 \%$ of non-financial industry in Pakistan. It can influence the performance of other sectors by its financial decision making and actions thereof. The researcher aims to explore the factors that determine firm's performance in textile sector of Pakistan so that the financial performance can be groomed in overall non-financial sector of Pakistan. The researcher's objective is to find out the different factors which are significantly affecting firm's performance in textile sector of Pakistan for the period 2005-2010.

\subsection{Research Questions}

The researcher wants to explore the current study with reference to the following research questions:

What factors are significantly impacting the firm's performance in textile industry of Pakistan?

Do the observed factors also consistent with the previous researcher's findings.

\section{Literature Review}

A large number of previous studies relating to firm's performance or sometimes corporate performance has identified a number of factors that empirically and even significantly affecting the firm's performance. There are a little number of research findings available in Pakistani context relating to firm's performance however the foreign researchers has done a lot in this context. The researcher used the framework of Zeitun and Tian (2007) with the extension in their regression model by adding liquidity and non-debt tax shield and applied this regression model simultaneously on textile and food sectors of Pakistan. The findings of Zeitun and Tian (2007) indicated that leverage has a significant and negative relationship with firm's performance. They used leverage, growth, size, tax, risk and tangibility as independent variable to see their effect on firm's performance. They concluded that firm's size and tax have positive and significant relationship with firm's performance while risk and tangibility have negative 
and significant relationship with firm's performance. Memon, Bhutto and Abbas (2010) concluded in their study of capital structure and firm's performance on textile sector that the companies in this sector are performance below optimum level of capital structure and also fail to achieve the economies of scale. Nosa and Ose (2010) found that effective funding required for the growth and development of the corporations in Nigeria. They suggested enhancing the regulatory framework for increasing the firm's performance by focusing on risk management and corporate governance. Onaolapo and Kajola (2010) found a significant and negative relationship between debt ratio and firm's financial performance. The study conducted by Krishnan and Moyer (1997) found a negative and significant relationship between leverage and firm's performance while other factors affecting firm's performance positively includes size, growth, tax and risk. Jensen and Meckling (1976) found two types of agency cost; agency cost of equity holders and agency cost of debt holders. They concluded that a conflict of interest arises between the management and the shareholders when management take decision against the interest of shareholders and another conflict arises when the shareholder act against the interest of debt holders. William (1987) found that decision for high leverage by the management decreases the conflict between management and shareholders. The leverage can work as disciplinary device that controls the management from wasting their firm's resources according to Grossman and Hart (1982). The researcher in the current study used short term as well as long term debts as proxy for leverage and also the other factors like growth, size, tax, risk, tangibility, liquidity and non-debt tax shield for measuring their impact on firm's financial performance in textile as well as food sector comparatively for the period 2005-2010.

\section{Data and Methodology}

\subsection{Data and Source}

The type of data is panel/longitudinal and has been created from the State Bank of Pakistan's annual publication "Financial Statement Analysis of companies (non-financial) listed in Karachi Stock Exchange for the period 2005-2010". This statement contains the 6 years financial figures of 12 different sectors relating to non-financial industry having 411 firms in total and available online at www.sbp.org.pk while the researcher selected the Textile sector because it covers the greatest part of overall population of non-financial industry in Pakistan.

The sample consists of 139 companies from textile sector of Pakistan. The findings of the current study is applicable on all sectors of non-financial industry of Pakistan as the sample selected covers $4.0 \%$ approximately of the whole population of non-financial industry.

It is not applicable on financial industry like banks and insurance sector as their capital structure is entirely different from non-financial sector.

\subsection{Econometric Regression Model}

For regression analysis of Panel data, there are three methods available for their regression like fixed effect, Random effect and constant coefficient regression model. The choice between fixed effect and random effect is finalized by hausman specification test (1978) while the choice between random effect and constant coefficient model is finalized by Lagrange multiplier test. As there is a large number of companies in the current study while the time 
period is small so the data type is short panel according to Baltagi (2005). The researcher expects a cross sectional fixed effect with constant in the current study and developed the following regression model for the estimation of current study:

$$
\begin{aligned}
& Y_{i t}=\alpha_{1}+\sum_{i=1}^{n-1} \boldsymbol{a}+\boldsymbol{u i}+\beta 1(L V)_{i t}+\beta 2(G R)_{i t}+\beta 3(S Z)_{i t}+\beta 4(R K)_{i t}+\beta 5(T X)_{i t} \\
& +\beta 6(T N)_{i t}+\beta 7(L Q)_{i t}+\beta 8(N D)_{i t}+\sum_{i=1}^{n} \boldsymbol{\beta j} \boldsymbol{j} \boldsymbol{i t}+U_{i t}
\end{aligned}
$$

Where

$Y_{i t}=$ Firm's Financial Performance over time. This variable is indicated by Return on Investment (ROI)

$\alpha_{1}+\sum_{i=1}^{n-1} \boldsymbol{a}+\boldsymbol{u} \boldsymbol{i}=$ Constant coefficient including cross sectional fixed effect

$\beta_{1}-\beta_{8}=$ Regression coefficients for measuring independent variables

$\mathrm{LV}=$ Leverage

$\mathrm{GR}=$ Growth

$\mathrm{SZ}=\mathrm{Size}$

RK = Risk

$\mathrm{TX}=\mathrm{Tax}$

$\mathrm{TN}=$ Tangibility

LQ = Liquidity

ND $=$ Non-debt Tax shield

$\sum_{i=1}^{n} \boldsymbol{\beta} \mathbf{j X i t}+U_{i t}=$ Error component showing unobserved factor

\subsection{Variables and Hypothesis Development}

The previous studies have shown a number of proxies for measuring firm's financial performance like ROA, ROE, Tobin's Q, EPS and ROI. Some of these variable required current market data like Tobin's Q. The researcher in the current study used Return on asset (ROI) as dependent variable for measuring firm's financial performance while the independent variables includes short term and long term leverage, growth, firm's size, risk, tax, tangibility of fixed assets, liquidity and non-debt tax shield (depreciation).

The description of each variable and their expected signs are given below in the following 
table:

Table 1. Explanation of Dependent and Independent variables and Expected signs

\begin{tabular}{|c|l|l|}
\hline \multicolumn{3}{|c|}{ Dependent Variable } \\
\hline \multicolumn{2}{|c|}{ EBIT/Total Assets } \\
\hline ROI & \multicolumn{1}{|c|}{ Independent Variables } \\
\hline Variables & \multicolumn{1}{|c|}{ Description } & Expected Signs \\
\hline Leverage & Short term debt/Total assets, Long term debt/Total Assets & Negative \\
\hline Growth & $\Delta$ Total Assets/ Total Assets & Positive \\
\hline Size & Natural Log of Total Sales & Positive \\
\hline Risk & EBIT/Earning after interest and Tax & Positive \\
\hline Tax & Current year's Tax/Earnings before Tax & Positive \\
\hline Tangibility & Fixed Assets/Total Assets & Positive \\
\hline Liquidity & Current Assets/Current Liabilities & Positive \\
\hline NDTS & EBIT + Depreciation/Total Assets & Positive \\
\hline
\end{tabular}

On the basis of above table the relationships between dependent and independent variables have been developed in the following hypothesis:

$H_{1}$ : Leverage (short \& long term) should have a negative impact on firm's performance.

$\mathrm{H}_{2}$ : Growth should have a positive impact on firm's performance.

$H_{3}$ : Firm's size should have a positive impact on firm's performance.

$H_{4}$ : There should be a positive relationship between risk and firm's performance.

$H_{5}$ : There should be a positive relationship between tax and firm's performance

$H_{6}$ : Tangibility should have a positive relationship with firm's performance.

$H_{7}$ : Liquidity should have a positive relationship with firm's performance.

$H_{8}$ : There is a positive relationship between Non-debt tax shield and firm's performance.

\section{Regression Analysis and Discussion on Findings}

The researcher used STATA 11 software for the regression analysis of the current study. The dependent variable is firm's performance measure ROI while the independent variables includes Leverage (short, long), Growth, Size, Risk, Tax, Tangibility, Liquidity and Non-debt tax shield. The descriptive statistics showing mean, standard deviation, minimum and maximum values of textile sector indicated in table 2 while correlation matrix of textile sector is indicated in table 3 . The regression result using one-way fixed effect model is indicated in table 4 . The presence of fixed cross sectional effect is evidenced by the significant results of hausman test which validate the name of this model as one way-fixed effect model according to Baltagi (2005).

Table 2. Descriptive Statistics

\begin{tabular}{|l|l|l|l|l|}
\hline \multicolumn{1}{|c|}{ Variables } & Mean & SD & Min & Max \\
\hline Return on Investment (ROI) & .0231793 & .1554565 & -1.71287 & 1.736175 \\
\hline Short term Leverage (S-Lev) & .5139861 & .2567038 & .0085605 & 2.546073 \\
\hline Long term Leverage (L-Lev) & .2236888 & .2091147 & 0 & 1.730722 \\
\hline
\end{tabular}




\begin{tabular}{|l|l|l|l|l|}
\hline Growth (GR) & .0337597 & .2263425 & -2.86857 & .9645731 \\
\hline Firm's Size (SZ) & 13.88058 & 1.417079 & 7.34601 & 17.26663 \\
\hline Risk (RK) & 1.388222 & 4.136975 & -42.9379 & 73.95914 \\
\hline Tax (TX) & .8204285 & 13.75174 & -58.7819 & 381.2666 \\
\hline Tangibility (TN) & .9245616 & .4761682 & 0 & 5.93239 \\
\hline Liquidity (LQ) & 1.045564 & 1.070488 & .04 & 10.55 \\
\hline Non-debt Tax shield (ND) & .1021373 & .5978221 & -10.9418 & 5.070107 \\
\hline
\end{tabular}

The above table 2 indicates the descriptive statistics like Mean, Standard deviation, Min and Maximum of Firm's performance (ROI) and other firm's specific factors like Leverage, Growth, Size, Risk, Tax, Tangibility, Liquidity and Non-debt tax shield (Depreciation) during the period 2005-2010 for Textile sector of Pakistan. The above table indicates that short term leverage has an average (mean) value as $51 \%$ in textile sector's firm's performance approximately, while long term leverage showing (mean) value as $22 \%$ in Textile sector. The firm's Size in Textile sector on average (mean) value showing $139 \%$.

Table 3. Correlation Matrix for Textile Sector

\begin{tabular}{|l|l|l|l|l|l|l|l|l|l|l|}
\hline & ROI & S-LV & L-LV & GR & SZ & RK & TX & TN & LQ & ND \\
\hline ROI & 1.000 & & & & & & & & & \\
\hline S-LV & -0.056 & 1.000 & & & & & & & & \\
\hline L-LV & -0.132 & -0.079 & 1.000 & & & & & & & \\
\hline GR & 0.089 & -0.109 & -0.108 & 1.000 & & & & & & \\
\hline SZ & 0.137 & -0.194 & -0.129 & 0.223 & 1.000 & & & & & \\
\hline RK & 0.057 & 0.003 & -0.030 & 0.002 & 0.063 & 1.000 & & & & \\
\hline TX & -0.003 & 0.026 & -0.013 & -0.003 & -0.018 & -0.007 & 1.000 & & & \\
\hline TN & -0.106 & 0.264 & 0.262 & -0.277 & -0.413 & -0.041 & -0.000 & 1.000 & & \\
\hline LQ & 0.039 & -0.204 & -0.121 & -0.015 & 0.051 & 0.029 & -0.036 & -0.101 & 1.000 & \\
\hline ND & 0.705 & -0.044 & -0.092 & 0.060 & 0.053 & 0.017 & -0.609 & -0.045 & 0.045 & 1.000 \\
\hline
\end{tabular}

The above table 4.2 indicates the correlation matrix of dependent and independent variables in textile sector of Pakistan for the period 2005-2010. It indicates that short term and long term leverage including tax and tangibility having negative correlation with firm's performance while growth, size, risk, liquidity and non-debt tax shield having positive correlation with firm's performance in textile sector of Pakistan. The highest correlation is indicated between non-debt tax shield and firm's performance as 0.71 approximately according to the above table.

Table 4. Regression Results - One way fixed effect regression model Dependent Variable = Firm's Performance (ROI)

\begin{tabular}{|c|r|r|r|r|}
\hline Independent Variables & \multicolumn{2}{|c|}{$1^{\text {st }}$ Model $\left(\beta_{1}=S\right.$ - $\left.L V\right)$} & \multicolumn{2}{c|}{$2^{\text {nd }}$ Model $\left(\beta_{1}=L-L V\right)$} \\
\hline & Coefficients & P-values & Coefficients & P-values \\
\hline Leverage (S-Lev, & -.0315 & $* *$ & .01988 & 0.2 \\
L-Lev) & 93 & 0.026 & 23 & 21 \\
\hline Growth (GR) & -0.014 & 0.2 & -.0124 & 0.3 \\
& 184 & 39 & 429 & 02 \\
\hline Firm's Size (SZ) & .01869 & $* 0$. & .01889 & $* 0.000$ \\
& 4 & 000 & 60 & \\
\hline Risk (RK) & .00142 & $* *$ & .00144 & $* * 0.021$ \\
& 3 & 0.023 & 25 & \\
\hline
\end{tabular}




\begin{tabular}{|c|c|c|c|c|}
\hline $\operatorname{Tax}(\mathrm{TX})$ & $\begin{array}{r}.00775 \\
3\end{array}$ & $\begin{aligned} * 0 . \\
000\end{aligned}$ & $\begin{array}{r}.00779 \\
07\end{array}$ & $\begin{array}{l}* * 0 . \\
000\end{array}$ \\
\hline Tangibility (TN) & $\begin{array}{r}-.0072 \\
14\end{array}$ & $\begin{array}{r}0.5 \\
11\end{array}$ & $\begin{array}{r}-.0116 \\
991\end{array}$ & $\begin{array}{r}0.2 \\
98\end{array}$ \\
\hline Liquidity (LQ) & $\begin{array}{r}-.0007 \\
47\end{array}$ & $\begin{array}{r}0.8 \\
43\end{array}$ & $\begin{array}{r}-.0002 \\
636\end{array}$ & $\begin{array}{r}0.9 \\
44\end{array}$ \\
\hline $\begin{array}{l}\text { Non-debt Tax shield } \\
\text { (ND) }\end{array}$ & $\begin{array}{r}.29488 \\
3\end{array}$ & $\begin{array}{l}* 0 . \\
000\end{array}$ & $\begin{array}{r}.29660 \\
95\end{array}$ & $\begin{array}{r}* 0 . \\
000\end{array}$ \\
\hline Constant & $\begin{array}{r}-.2505 \\
96\end{array}$ & $\begin{array}{r}0.0 \\
01\end{array}$ & $\begin{array}{r}-.2707 \\
327\end{array}$ & $\begin{array}{r}0.0 \\
00\end{array}$ \\
\hline $\begin{array}{l}\text { Number of } \\
\text { Observations }\end{array}$ & \multicolumn{2}{|r|}{$=834$} & \multicolumn{2}{|r|}{$=834$} \\
\hline No of Groups & \multicolumn{2}{|r|}{$=139$} & \multicolumn{2}{|r|}{$=139$} \\
\hline \multirow[b]{2}{*}{$\begin{array}{l}\text { Overall Model } \\
\text { Fitness }\end{array}$} & \multicolumn{2}{|c|}{$F(8,687)=325.51$} & \multicolumn{2}{|c|}{$\mathrm{F}(8,687)=323.44$} \\
\hline & \multicolumn{2}{|c|}{ Prob $>F=0.0000$} & \multicolumn{2}{|c|}{ Prob $>F=0.0000$} \\
\hline R2 (Within) & \multicolumn{2}{|r|}{$=0.7913$} & \multicolumn{2}{|r|}{$=0.7902$} \\
\hline R2 (Between) & \multicolumn{2}{|r|}{$=0.7833$} & \multicolumn{2}{|r|}{$=0.7926$} \\
\hline R2 (Overall) & \multicolumn{2}{|r|}{$=0.7847$} & \multicolumn{2}{|r|}{$=0.7866$} \\
\hline \multirow[t]{2}{*}{ F-test that all $\mathrm{u}-\mathrm{i}=0$} & \multicolumn{2}{|c|}{$\mathrm{F}(138,687)=1.57$} & \multicolumn{2}{|c|}{$\mathrm{F}(138,687)=1.54$} \\
\hline & \multicolumn{2}{|c|}{ Prob $>F=0.0001$} & \multicolumn{2}{|c|}{ Prob $>F=0.0003$} \\
\hline Hausman test & \multicolumn{2}{|c|}{ Prob $>$ Chi2 $=0.000$} & \multicolumn{2}{|c|}{ Prob $>$ Chi2 $=0.007$} \\
\hline \multicolumn{5}{|c|}{$\begin{array}{c}\text { Note: The current table is generated by the output STATA } 11 \text { regression } \\
\text { result }\end{array}$} \\
\hline \multicolumn{5}{|c|}{$\begin{array}{c}* \text { significant at } 1 \% \text { level, } * * \text { significant at } 5 \% \text { level, } * * * \text { significant at } 10 \% \\
\text { level }\end{array}$} \\
\hline
\end{tabular}

The above table 4.3 indicates results of one-ways fixed effect regression model estimation. The overall model is statistically fit and significant in both sectors. It indicates that short term leverage is significant at 5\% level in textile sector and showing negative relationship with firm's performance and accepts the $1^{\text {st }}$ hypothesis. The negative relation between leverage and firm's performance is also consistent with the following researchers like Krisnan and Moyer (1997), Onaolapo and kajola (2010), Memon, Bhutto and Abbas (2010) and Zeitun and Tian (2007). It indicates that firm's performance in textile sector is significantly influenced by short term debts. Growth is not significant at any level and showing negative relationship which rejects the $2^{\text {nd }}$ hypothesis. However the negative relationship between growth and firm's performance is consistent with the similar findings of previous researchers Zeitun and Tian (2007) while the other researchers like Krishnan and Moyer (1997), Onaolapo and Kajola (2010), Memon, Bhutto and Abbas (2010) found positive relationship between firm's performance and growth. Firm's size is significant @1\% level and accepts the $3^{\text {rd }}$ hypothesis. This positive relationship is consistent with the following researchers like Onaolapo and Kajola (2010), Krishnan and Moyer (1997) and Zeitun and Tian (2007). It indicates that firm's size increases firm's performance in textile sector of Pakistan. Risk is significant at $5 \%$ level in textile sector. It is showing positive relationship which accepts $4^{\text {th }}$ hypothesis. This positive relationship between risk and firm's performance is also consistent with the previous researchers who found the same relationship like Memon, Bhutto and Abbas (2010) and Krishnan and Moyer (1997). It indicates that more risky firms tend to perform well in textile sector of Pakistan. Tax is significant at $1 \%$ level in textile sector and accepts $5^{\text {th }}$ hypothesis it is also consistent with the similar findings by Krishnan and Moyer (1997), Memon, Bhutto and 
Abbas (2010) and Zeitun and Tian (2007). Tangibility is not significant at any level in textile sector. It means that tangibility does not play a significant role for firm's performance in textile sector. Liquidity is not significant at any level in both sectors. It has negative relationship with firm's performance in textile sector that rejects the $7^{\text {th }}$ hypothesis. The non-debt-tax shield (depreciation) is significant at $1 \%$ level with positive relationship and accepts $8^{\text {th }}$ hypothesis. It means that non-debt tax shield plays an important and significant role for increasing firm's performance in textile sector of Pakistan.

\section{Conclusion and Recommendations}

The current study concluded that firm's performance in textile sector of Pakistan is significantly affected by Short term leverage, size, risk, tax and non-debt tax shield. The Researchers recommends that the textile sector of Pakistan should make its financial decision taking into consideration of the above said factors because textile sector is the largest sector in Pakistan for non-financial industry and it is considered as benchmark for other sectors in Pakistan. The Findings of the researcher are also consistent with the previous researchers. The Textile sector should preferably decrease their short term debt financing as it will decrease firm's financial performance while all other sector may increase it. The firm should use less short term debt as it neither provide tax shield advantage and not also cheap as long term debt financing.

\section{Policy Implications}

The current research findings empirically implies that the companies in textile sector of Pakistan has to make their policies by considering short term leverage, firm's size, financial risk, tax provision and non-debt tax shield (depreciation) in order to strengthen their performance. Short term leverage decreases performance significantly so the firms should avoid short term leverage while all other factors increases firm's performance in textile sector of Pakistan.

\section{Limitations and Suggestions}

The current study is limited and applicable to non-financial industry of Pakistan only. It is not applicable to financial sector as their capital structure is entirely different from non-financial sector. The researcher used book value measure for dependent and independent variables. The future research on firm's performance may be made through market value measures like Tobin's Q etc. The future research may also be conducted on financial sector using the same models and variables.

\section{References}

Baltagi, Badi, H., (2005), "Econometric analysis of Panel data, $3^{\text {rd }}$ edition", John wiley and sons Ltd.

Campbell, A., (2007), "Introduction to Econometrics", MIT.

Financial statement analysis of Non-financial companies listed in Karachi Stock Exchange for 
the period 2005-2010, Statistic and DWH department, State Bank of Pakistan.

Jensen, Meckling (1986), Agency cost of Free Cash Flows, Corporate Finance and Takeovers, American Economic Review, Issue 76, PP 323-329.

Krishnan and Moyer (1997), Performance, Capital Structure and Home Country: An analysis of Asian Countries, Global Finance Journal, Issue 8(1), PP 129-143.

Memon, Bhutto and Abbas, (2010), Capital Structure and firm's performance: A case of Textile sector of Pakistan, Asian Journal of Business and Management Sciences, Vol 1, issue 9, PP 9-15.

Modigliani, F., \& Miller, M., (1958), The Cost of Capital, Corporation Finance and the theory of investment, The American Economic Review, Vol 48, Issue 3, 261-297.

Nosa, \& Ose, (2010), Capital Structure and Corporate Performance in Nigeria: An empirical investigation, Journal Of Management Sciences, Vol 1, Issue 1, 43-52.

Onaolapo, \& Kajola (2010), “ Capital structure and Firm's Performance: Evidence from Nigeria", European Journal of Economics, Finance and Administration Sciences, Issue 25, 70-82.

Park. (2009), Linear regression models for panel data using SAS, STATA, LIMDEP and SPSS, Indiana University.

Pratheepkanth, P., (2011), Capital Structure and Financial performance: Evidence from Selected Business Companies from Colombo Stock Exchange Srilanka, International Referred Research Journal, Vol 2, Issue 2, 171-183.

San, O. T., \& Heng, T. B., (2011), Capital Structure and Corporate Performance in Malaysian Construction Sector, International Journal of Humanities and Social Sciences, 1(2), 28-36.

Scott, D. E., (1972), Evidence on the Importance of Financial Structure, Journal of Finance and Management, Issue 1, 45-50.

Shah, S.M., \& Amir (2007), The Determinants of Corporate Debt Policy, Pre and Post Financial Market Reforms: A case from Textile Industry of Pakistan, The Pakistan Development Review, 46(4), 465-478.

Smith, C.W., \& Watts, R. L., (1992), The Investment opportunity set and corporate financing dividend and compensation policies, Journal of Financial Economics, 32, 263-292.

Williamson, O., (1988), Corporate Finance and Corporate Governance, Journal of Finance, Issue 43, 567-591.

Wooldridge, J.M., Introductory Econometrics: A modern Approach, $2^{\text {nd }}$ Edition.

Zeitun, R., \& Tian, G. G., (2007), "Capital Structure and Corporate performance: Evidence from Jordan”, Australasian Accounting, Business and Finance Journal, Vol 1, Issue 4, article 3.

Zeitun, R., (2009), Ownership Structure, Corporate Performance and Failure: Evidence of 


\section{Macrothink}

Business and Economic Research

ISSN 2162-4860 2013, Vol. 3, No. 2

Panel Data of emerging market, a case of Jordan, Corporate Ownership and Control, Vol 6, Issue 4, 96-114.

\section{Copyright Disclaimer}

Copyright reserved by the author(s).

This article is an open-access article distributed under the terms and conditions of the Creative Commons Attribution license (http://creativecommons.org/licenses/by/3.0/). 